
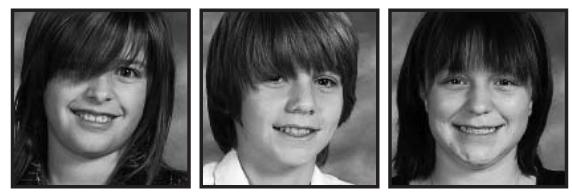

\title{
Commentary:
}

\section{Elementary Students Discuss Literacy}

\section{Sonora Lemieux, Benoît Mallette \& Shannon Prevost O'Dowd, Courtland Park International School}

\begin{abstract}
In this interview, three grade six students discuss their perspectives on literacy. Sonora, Shannon, and Benoît explore the role of peer collaboration, fun, and the various ways that they learn and share their learning with others. The students express their enjoyment of reading and emphasize the value of challenging oneself and persevering when a book or a project becomes difficult. They explain the advantages of pneumonic devices and other "tricks" for learning items such as multiplication tables, and elaborate with anecdotes involving fellow students as well as adults. Common to all of the students' experiences are the benefits of multi-modal teaching and learning, and the advantages of incorporating art with auditory and visual information in literacy activities. These students also discuss the Internet as an important resource, citing its use for classroom inquiry as well as educational games. They recognize the importance of literacy for future success. Their advice to others is to work hard in school.
\end{abstract}

1. What does the word "literacy" mean to you? (0:47)

2. Can you talk about the different ways you use to understand things? (2:00)

3. What is your favourite way to learn? $(0: 14)$

4. Can you talk about the different ways you use to share what you know with other people? (2:53)

5. How did each of you become a writer? How did each of you learn how to read? (2:14)

6. What do you think teachers need to emphasize to help students understand things? (1:11)

7. How should teachers help students to share their learning and their ideas with others? (1:58) 
8. How do students help each other in literacy learning? (1:27)

9. What is the favourite project that you have ever done in school? (5:44)

10. How do you think you learn best? (0:56)

11. When you grow up and go out in the world how do you think what you are learning in school is going to help you? $(1: 18)$

12. If you had a piece of advice to give to a younger one coming in to school, what advice would you give? (1:21)

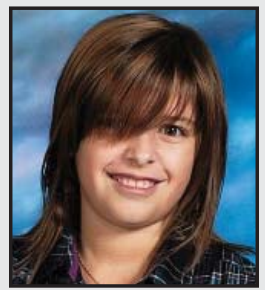

Sonora Lemieux is an eleven-year-old student at Courtland Park International School. She takes horseback riding lessons and funky hip-hop dance courses. She loves to laugh and hang out with her friends. Her favourite subjects are English and French because she will be able to communicate in both languages easily. She wants to be an actress in the future because she loves to have fun!

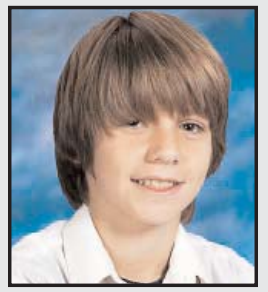

Benoît Mallette is a real sports enthusiast and enjoys hockey, soccer and football. Each night when he has time, he reads for $\mathbf{2 0}$ minutes in French and English. In French he likes to read books from the Les Intouchables publishing house, such as Pakkal, Darhan and Leonis. In English he prefers hockey books as well as works from young reader authors like Jerry Spinelli.

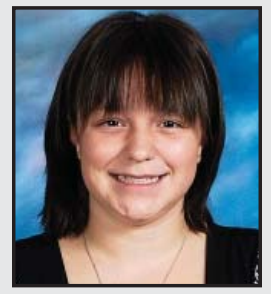

Shannon Prevost O'Dowd is passionate about ringette and soccer. In fact, she is going in a soccer program in high school at Heritage Regional High School. She will be graduating from Courtland Park International School this year. She loves reading and math. Most of all, she likes playing with her friends. She won the ringette provincial championship in Sept-Îles, with her father as her coach. 